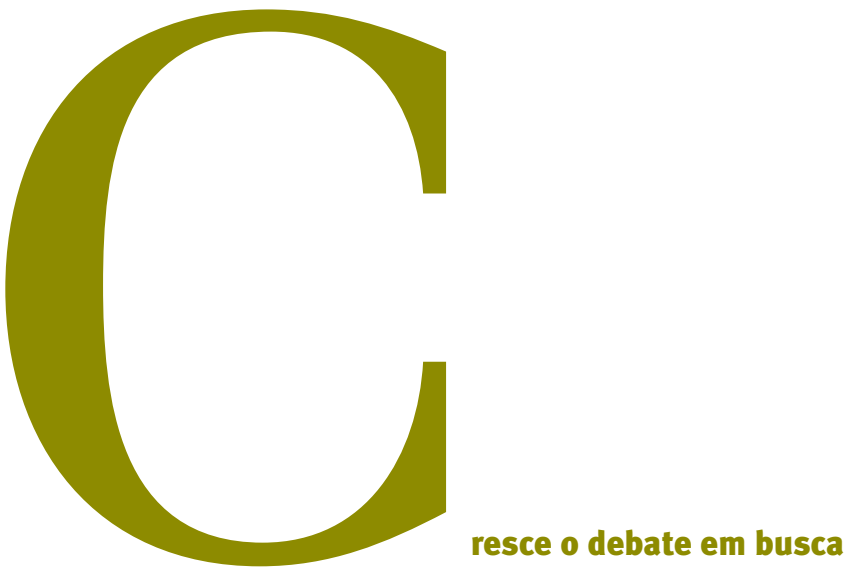

de consenso em relação aos conceitos e conteúdos da educação integral. Para contribuir com essa discussão e ampliar o conhecimento sobre o tema, esta edição do CADERNOS CENPEC procura lançar luz sobre o "estado da arte" da educação integral no Brasil, apresentando as reflexões e as práticas que se embasam nessa concepção ou bebem nessa referência.

O tema da educação assume uma centralidade indiscutível. É unânime que ela deve ser apoiada e melhorada, e que todos, além dos governos e da iniciativa privada, somos responsáveis pelos resultados que precisam ser alcançados nos próximos anos em relação à inclusão justa e qualificada de todos os brasileiros no mundo do conhecimento.

Na área pública, organizações governamentais, sociedade, organizações sociais e cidadãos vocalizam seu desejo de uma boa educação para crianças e jovens, considerada agora numa perspectiva mais ampla, como já indicam as leis nacionais. Nesse cenário, ressurge a idéia da educação integral, pensada e concretizada de variados modos e a partir de diferentes concepções, todos eles devedores do entusiasmo e da ousadia de Anísio Teixeira e herdeiros das contradições inerentes aos projetos mais arrojados de mudança.

Ressurge como expectativa de ampliação do tempo de estudo, via sistema público de ensino, como estratégia de convocação de muitos espaços de aprendizagem, como possibilidade de alargamento da participação de diferentes políticas sociais e da sociedade organizada no processo educativo e, também, como alternativa importante para a melhoria dos índices educacionais do País.

A educação integral renasce sob a inspiração da Lei de Diretrizes e Bases da Educação Nacional - LDB, que prevê o aumento progressivo da jornada escolar para o

\section{O ressurgimento da educação integral}

regime de tempo integral (Artigos 34 e 87) e, ao mesmo tempo, reconhece e valoriza as iniciativas de instituições que desenvolvem, como parceiras da escola, experiências extra-escolares (LDB, Artigo 3, item 10).

Os artigos e estudos de caso que apresentamos focalizam o tempo e o espaço para aprender e permitem relembrar aprendizagens nascidas de processos intencionais e planejados e aquelas construídas no cotidiano, de maneira simples e distraída, como as que experimentamos com pais, mães e comunidade. Permitem também entender a semeadura do conhecimento, em experiências de ousadia e esperança, e outras, em que o conflito e o desafio instigam a insistência pedagógica e a consciência política de educadores sociais, pais e professores em todo o Brasil.

Sob a lona colorida de circo, na caatinga nordestina ou na metrópole agitada, as crianças e adolescentes vivenciam diferentes experiências educativas, seja em programas pós-escolares, seja na jornada escolar ampliada, construindo composições curriculares que procuram atender a uma demanda das famílias pelo cuidado pedagógico com seus filhos e pela possibilidade de obter, para eles, por meio da educação integral, um passaporte para a independência econômica e a melhoria social.

É importante lançar um olhar sobre a educação integral, considerando-a um processo de redescoberta da criança e do adolescente como sujeitos de direito em sua inteireza humana. É também uma oportunidade para ativar e estimular o compromisso de todos com a educação pública brasileira, que ainda precisa de uma revolução, a cada dia e em cada contexto, para a superação de décadas de atraso educacional.

\section{Maria Alice Setubal \\ Diretora-Presidente do}

